\title{
Development of a Press-Hardened Steel Suitable for Thin Slab Direct Rolling Processing
}

\begin{abstract}
JEWOONG LEE and BRUNO C. DE COOMAN
The thin slab casting and direct rolling process is a hot-rolled strip production method which has maintained commercial quality steel grades as a major material in many industrial applications due to its low processing cost. Few innovative products have however been developed specifically for production by thin slab direct rolling. Press hardening or hot press forming steel grades which are now widely used to produce structural automotive steel parts requiring ultrahigh strength and formability may however offer an opportunity for thin slab direct rollingspecific ultra-high strength products. In this work, a newly designed press hardening steel grade developed specifically for thin slab direct rolling processing is presented. The press hardening steel has a high nitrogen content compared with press hardening steel grades produced by conventional steelmaking routes. Boron and titanium which are key alloying additions in conventional press hardening steel such as the $22 \mathrm{MnB} 5$ press hardening steel grade are not utilized. $\mathrm{Cr}$ is added in the press hardening steel to obtain the required hardenability. The properties of the new thin slab direct rolling-specific $22 \mathrm{MnCrN} 5$ press hardening steel grade are reviewed. The evolution of the microstructure and mechanical properties with increasing amounts of $\mathrm{Cr}$ additions from 0.6 to $1.4 \mathrm{wt}$ pct and the effect of the cooling rate during diequenching were studied by means of laboratory simulations. The selection of the optimum chemical composition range for the thin slab direct rolling-specific $22 \mathrm{MnCrN} 5$ steel in press hardening heat treatment conditions is discussed.
\end{abstract}

DOI: $10.1007 / \mathrm{s} 11661-014-2613-6$

(C) The Minerals, Metals \& Materials Society and ASM International 2014

\section{INTRODUCTION}

THE thin slab casting and direct rolling (TSDR) process is essentially a low cost alternative for the production of thin gauge conventionally hot-rolled steel strip. TSDR-specific advantages include reduction of capital investments, low energy consumption, and substantially reduced $\mathrm{CO}_{2}$ greenhouse gas emissions. ${ }^{[1-6]}$ The original TSDR technology was the Compact Strip Processing (CSP) technology. After the development of the CSP technology, several alternative TSDR designs have been developed to maximize the advantages of TSDR as compared with conventional hot strip mill processing.

The TSDR technology has up to now been used mostly to produce commercial steel grades. The present contribution shows that advanced ultra-high strength automotive steel grade can also be developed for TSDR processing. Hot press forming (HPF), also known as hot stamping, press hardening, or die-quenching, is a technology to produce advanced ultra-high strength steels (AHSS) for automotive applications. The HPF

JEWOONG LEE, Graduate Student, is with the Graduate Institute of Ferrous Technology, Pohang University of Science and Technology, Pohang, South Korea. BRUNO C. DE COOMAN, Professor, is with the Graduate Institute of Ferrous Technology, Pohang University of Science and Technology, and also Director, with the Materials Design Laboratory, Pohang University of Science and Technology, Pohang,

South Korea. Contact e-mail: decooman@postech.ac.kr

Manuscript submitted April 10, 2014.

Article published online October 18, 2014 process was originally developed by Norrbottens Järnverks in 1973 to produce press-hardened steel (PHS). It is now widely used to produce passenger safety antiintrusion parts and structural reinforcements such as door beams, impact beams, bumpers, pillars, and tunnels. ${ }^{[7-9]}$ The most widely used PHS grade is 22MnB5. This steel grade has an ultra-high ultimate tensile strength (UTS) $(\sim 1500 \mathrm{MPa})$. The total elongation is rather limited, approximately 6 pct, because of its fully martensitic microstructure. ${ }^{[10]}$

In this work, the development of a TSDR-specific PHS is presented. Figure 1 shows a schematic flow chart for the production of conventional cold-rolled 22MnB5 and compares it to the production route for the new TSDR-specific PHS. In general, cold-rolled $22 \mathrm{MnB} 5$ steel is produced by a series of process step shown in Figure 1(a). 22MnB5 is first continuously cast. The slab is cooled down to room temperature and reheated to about $1523 \mathrm{~K}\left(1250{ }^{\circ} \mathrm{C}\right)$ prior to hot-rolling. The hot-rolled microstructure contains ferrite and pearlite. The hot-rolled strip is pickled and cold-rolled to a thickness of about $1.5 \mathrm{~mm}$. Annealing for recrystallization and coating of the full hard strip is carried out in a continuous galvanizing line (CGL) or a continuous aluminizing line. An ultra-high strength fully martensitic microstructure is obtained by the HPF process using water-cooled dies. ${ }^{[1-15]}$

The production of the TSDR-compatible PHS steel is shown in Figure 1(b). The hot-rolled strip is produced in a more cost-effective manner than $22 \mathrm{MnB} 5$ by means of 


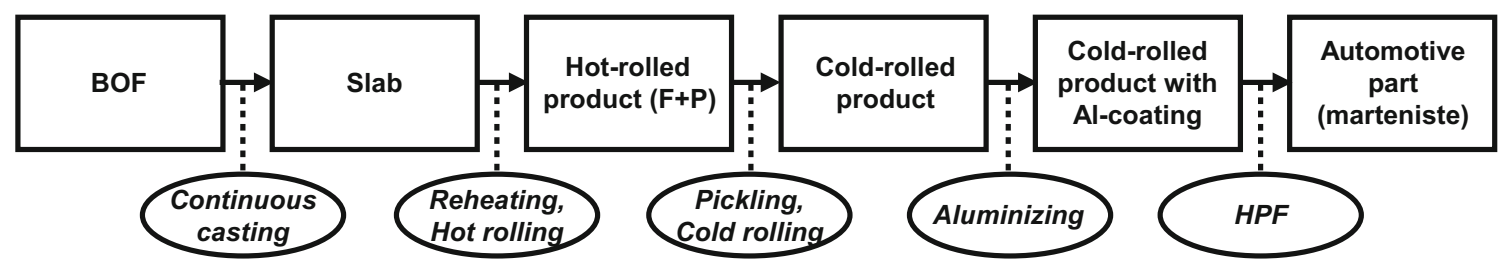

(a)

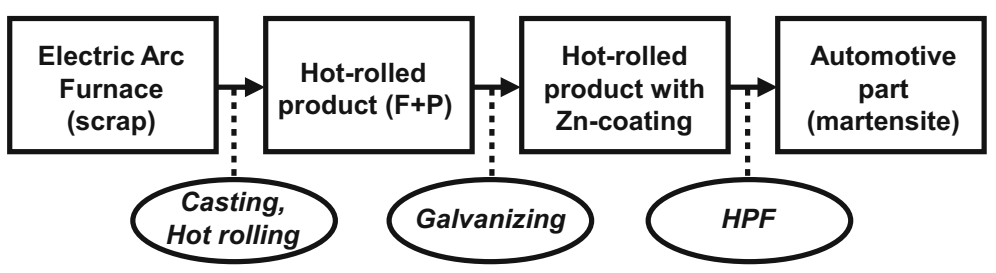

(b)

Fig. 1-Schematic flow charts for the production of ultra-high strength automotive parts using $(a)$ conventional cold-rolled $22 \mathrm{MnB} 5$ and $(b)$ the proposed PHS produced by TSDR and continuous galvanizing. The proposed PHS processing is considerably shorter than the standard $22 \mathrm{MnB5}$ processing.

TSDR processing. A thin slab is continuously cast and directly hot-rolled to the designated final product thickness. ${ }^{[6,16,17]}$ The fully recrystallized TSDR hotrolled product, with a ferrite and pearlite microstructure, can be directly $\mathrm{Zn}$ coated in a combined pickling and hot-dip coating line. The coating of the steel does not require a high temperature recrystallization-annealing stage. "Heat-to-coat" to the liquid metal temperature, i.e., $743 \mathrm{~K}\left(470{ }^{\circ} \mathrm{C}\right)$ for hot-dip galvanizing, is sufficient. This low temperature hot-dip coating implies that the TSDR-specific PHS alloy can be coated in a more cost-effective manner compared with the conventional 22MnB5 PHS grade.

TSDR processing may involve considerable thin slab cooling in non-standard operation conditions. In-line heating, by means of a tunnel furnace, induction heating or a special coil-box type furnace is however always available to adjust the temperature prior to rolling. In non-standard operating conditions which require a considerable reheating, a larger austenite grain size will be generated prior to rolling. Although this may influence the final grain size and morphology of the hot-rolled microstructure, the impact of the reheating will be minor as the final in-service properties of PHS are obtained in during the press hardening process. In this process, the initial PHS microstructure is once again fully austenitized and press-formed, and the strained microstructure is transformed to martensite.

The TSDR-compatible PHS alloy design is based on the use of the higher $\mathrm{N}$ content, resulting from the electric arc furnace (EAF)-based steel production route. $\mathrm{B}$ and $\mathrm{Ti}$ are important alloying additions in conventional 22MnB5 PHS. B is added to increase the hardenability. Since solute B segregates to the austenite grain boundaries before quenching, it impedes the nucleation of pro-eutectoid ferrite and thus promotes the formation of harder phases such as bainite and martensite. B must be in solute form and allowed to segregate to the austenite grain boundaries in order to be effective as a hardenability agent. $\mathrm{Ti}$ is typically added to the steel composition to protect $\mathrm{B}$ as $\mathrm{B}$ is a strong nitride former. ${ }^{[18]}$ In the new alloy concept, $\mathrm{N}$ is utilized as an additional solute strengthening addition. $\mathrm{Cr}$, rather than $\mathrm{B}$, is added to the steel composition to achieve the required hardenability and obtain a fully martensitic microstructure after die-quenching. In a conventional Ti-B PHS such as 22MnB5, solute B is added to achieve a sufficient hardenability. In the presence of a high $\mathrm{N}$ content, which is not stabilized by a strong nitride former such as $\mathrm{Ti}$, the formation of $\mathrm{BN}$ renders the $\mathrm{B}$ inactive as a hardenability agent. $\mathrm{Cr}$ was therefore used as an alternative hardenability agent in the present TSDR-compatible steel. The impact of $\mathrm{N}$ on the steel properties can be either positive or negative depending on the required application performance and the presence of other alloying elements. In the absence of a strong nitride former such as $\mathrm{Ti}$ and $\mathrm{Al}$, a high $\mathrm{N}$ content will usually result in inconsistent mechanical properties in hot-rolled products as a result of aging. This issue is however not relevant to the present TSDRcompatible PHS as it is fully re-austenitized and transformed to martensite during the HPF heat treatment. In the high-speed casting condition used in TSDR processing, the Ti-precipitates formed in the high temperature austenite region make the steel vulnerable to transverse cracking during casting. A Ti-free PHS is therefore more suitable for TSDR processing. The designation of this TSDR-compatible PHS grade is 22MnCrN5-4 for a nominal $\mathrm{Cr}$ content of 1 wt pet. Similar PHS alloys with different $\mathrm{Cr}$ contents are referred to as $22 \mathrm{MnCrN5}-\mathrm{X}$ in the present work.

\section{EXPERIMENTAL}

Hot-rolled 22MnCrN5-X strip with a thickness of $2.2 \mathrm{~mm}$ was prepared in the TSDR processing condition. The cast thin slab was directly hot-rolled to the designated 
Table I. Chemical Compositions of 22MnB5 and 22MnCrN5-X (in mass pet)

\begin{tabular}{lccccccc}
\hline Steels & $\mathrm{C}$ & $\mathrm{Si}$ & $\mathrm{Mn}$ & $\mathrm{Al}$ & $\mathrm{Cr}$ & $\mathrm{Ti}$ & $\mathrm{B}$ \\
\hline $22 \mathrm{MnB} 5$ & 0.22 & 0.22 & 1.25 & 0.03 & 0.16 & 0.04 & 0.002 \\
$0.6 \mathrm{Cr}$ & 0.22 & 0.25 & 1.25 & 0.03 & 0.60 & - & - \\
$0.8 \mathrm{Cr}$ & 0.22 & 0.25 & 1.25 & 0.03 & 0.80 & - & - \\
$1.0 \mathrm{Cr}$ & 0.22 & 0.25 & 1.25 & 0.03 & 1.00 & - & -0.010 \\
$1.2 \mathrm{Cr}$ & 0.22 & 0.25 & 1.25 & 0.03 & 1.20 & - & - \\
$1.4 \mathrm{Cr}$ & 0.22 & 0.25 & 1.25 & 0.03 & 1.40 & - & -0.010 \\
\hline
\end{tabular}

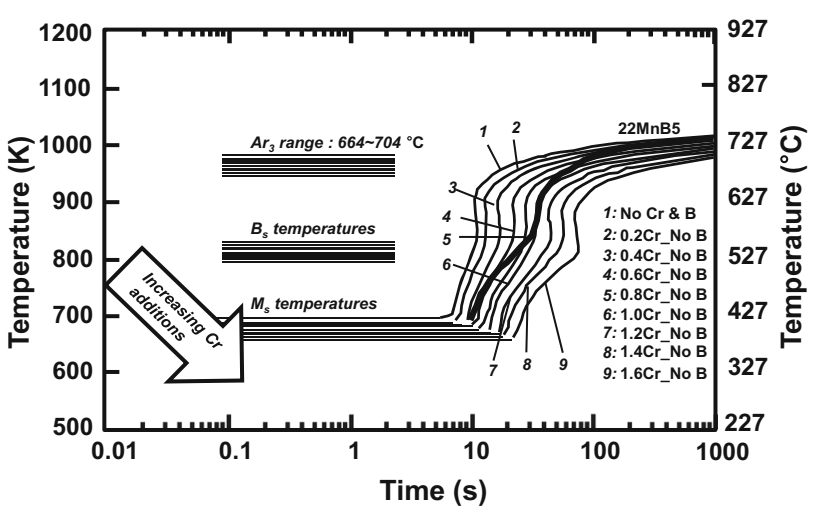

Fig. 2-Comparison of the time temperature transformation (TTT) diagrams for $22 \mathrm{MnB} 5$ and steels with different amounts of $\mathrm{Cr}$.

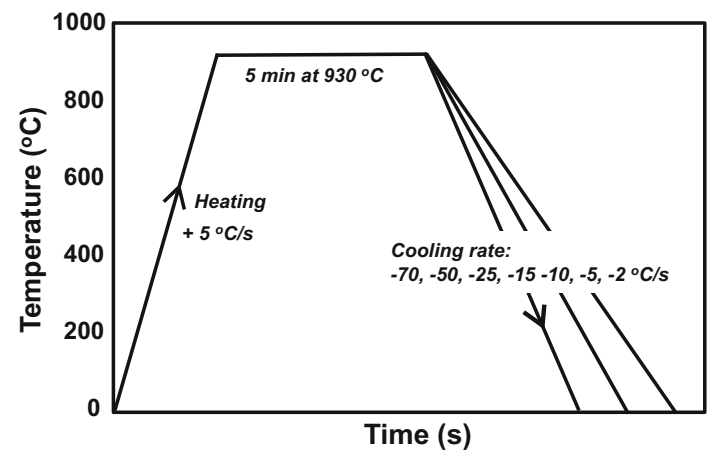

Fig. 3-Thermal cycle use to determine the CCT diagram of the 22MnCrN5-X alloys.

thickness unlike the procedure used in the conventional hot-rolling process. The compositions of the conventional 22MnB5 PHS grade and the TSDR-compatible PHS are listed in Table I. The $\mathrm{Cr}$ content in the 22MnCrN5-X PHS grade ranged from 0.6 to $1.4 \mathrm{wt}$ pct. The choice of this chemical composition was based on calculated transformation kinetics. Figure 2 shows the calculated CCT diagram for $22 \mathrm{MnB} 5$ and $22 \mathrm{MnCrN5}-\mathrm{X}$ steels with a $\mathrm{Cr}$ content in the range of 0.6 to $1.4 \mathrm{wt}$ pct. This TTT diagram can be viewed on the following website http:// calculations.ewi.org/vjp/secure/TTTCCTPlots.asp. The solid lines in Figure 2 indicate the start of the ferrite and bainite transformations for $22 \mathrm{MnB} 5$. The dotted lines are for the transformation kinetics of the 22MnCrN5-X steels.

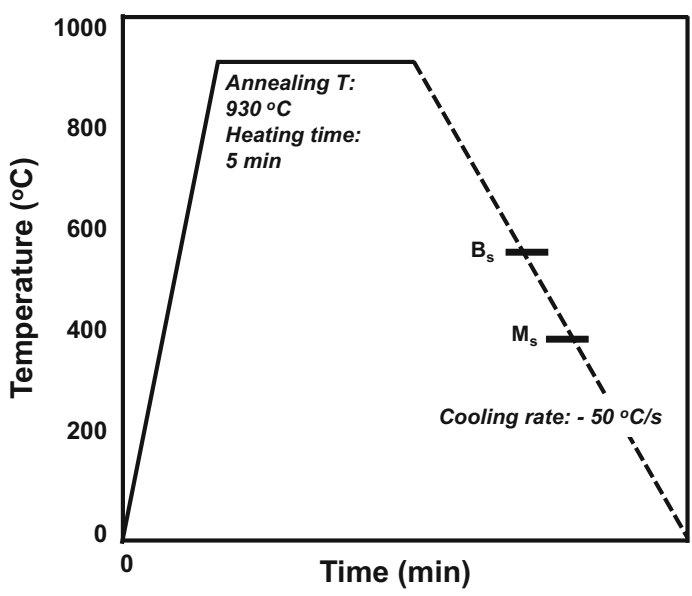

(a)

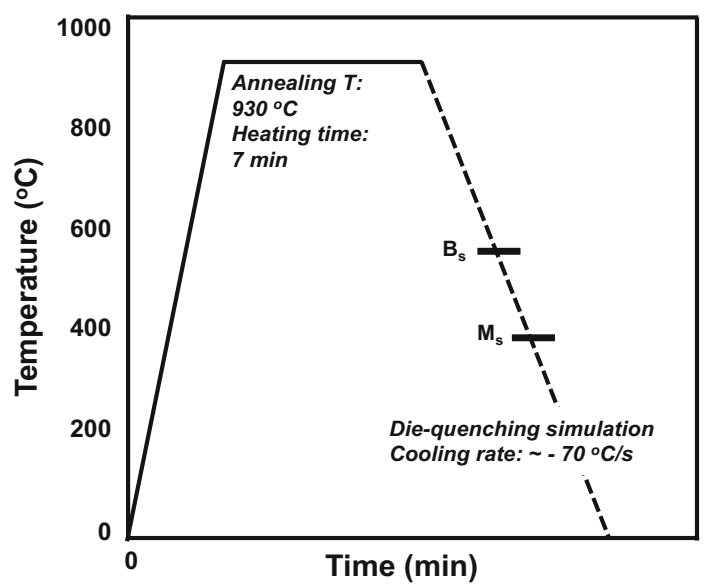

(b)

Fig. 4-Two different HPF heat treatment simulations: (a) 5 min at $1203 \mathrm{~K}\left(930{ }^{\circ} \mathrm{C}\right)$ with a $50{ }^{\circ} \mathrm{C} / \mathrm{s}$ cooling rate $(b) 7$ min at $1203 \mathrm{~K}$ $\left(930^{\circ} \mathrm{C}\right)$ with die-quenching.

The composition range of 0.6 to $1.4 \mathrm{wt}$ pct of $\mathrm{Cr}$ was determined on the basis of these TTT diagrams. The chemical composition of $22 \mathrm{MnCrN} 5-\mathrm{X}$ differs from that of $22 \mathrm{MnB} 5$ in terms of the $\mathrm{Cr}$ addition, the absence of Ti and $\mathrm{B}$ additions, and the higher $\mathrm{N}$ content. The $22 \mathrm{MnCrN} 5-\mathrm{X}$ steels were produced by means of a scrap-based EAF steel production route, which resulted in a higher $\mathrm{N}$ content compared with the $\mathrm{N}$ content of the conventional coldrolled 22MnB5 PHS grade.

Dilatometric tests were carried out to observe the effect of the $\mathrm{Cr}$ additions on the austenite decomposition kinetics for the formation of ferrite and bainite during cooling after 

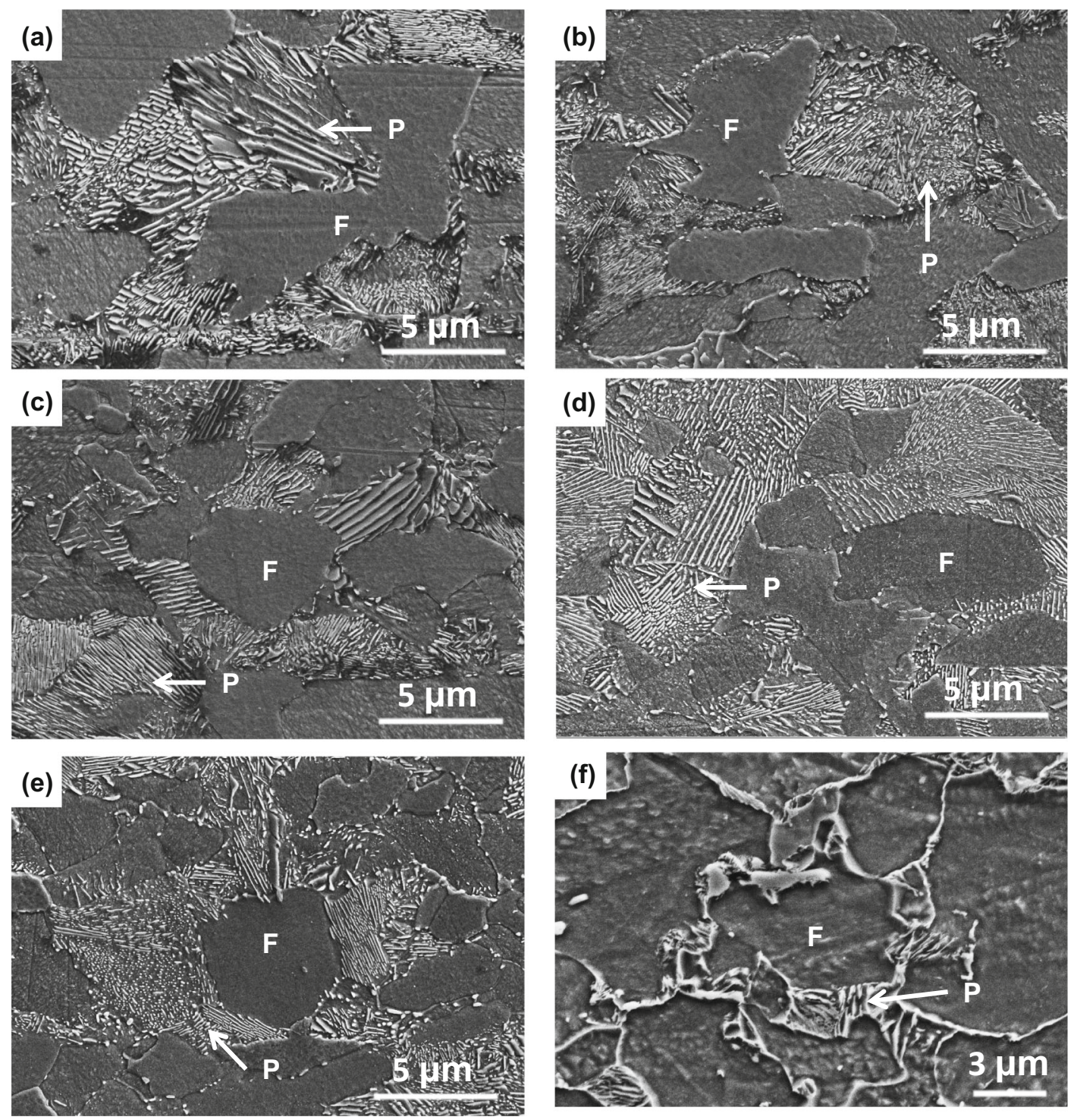

Fig. 5-Microstructure of hot-rolled 22MnCrN5-X with different Cr contents: (a) 0.6, (b) 0.8, (c) 1.0, (d) 1.2, and (e) 1.4 wt pct Cr.

austenitization. The samples were heated to $1203 \mathrm{~K}$ $\left(930^{\circ} \mathrm{C}\right)$ with a heating rate of $+5{ }^{\circ} \mathrm{C} / \mathrm{s}$. Figure 3 shows the heat cycle used to determine the CCT diagram. After austenitization at $1203 \mathrm{~K}\left(930{ }^{\circ} \mathrm{C}\right)$ for 5 minutes, the samples were cooled to room temperature using cooling rates in the range of -2 to $-70{ }^{\circ} \mathrm{C} / \mathrm{s}$.

Two types of HPF heat cycles were used to simulate industrial HPF processing using the $22 \mathrm{MnCrN5}$-X steel. The HPF heat treatment simulations are shown in Figure 4. In the first HPF heat treatment, the samples were heated to $1203 \mathrm{~K}\left(930{ }^{\circ} \mathrm{C}\right)$, held at this temperature for 5 minutes, and cooled to room temperature with a cooling rate of $-50{ }^{\circ} \mathrm{C} / \mathrm{s}$. In the second HPF heat treatment, the samples were heated to $1203 \mathrm{~K}\left(930{ }^{\circ} \mathrm{C}\right)$, held at this temperature for 7 minutes, and die-quenched to room temperature by means of flat water-cooled die plates.

Micrographs of the sample microstructure were obtained with a Zeiss Ultra 55 Field-Effect Emitter
Scanning Electron Microscope (FE-SEM) using a $10 \mathrm{kV}$ accelerating voltage. Tensile tests were carried out at $298 \mathrm{~K}\left(25^{\circ} \mathrm{C}\right)$ on a Zwick universal tensile testing machine using ASTM E8 specimens. The strain rate for the tensile tests was $10^{-3} \mathrm{~s}^{-1}$.

\section{RESULTS}

\section{A. Microstructure of TSDR-Processed 22MnCrN5-X}

Figure 5 shows microstructural changes of hot-rolled $22 \mathrm{MnCrN5}-\mathrm{X}$ as a function of the $\mathrm{Cr}$ content in the TSDR-processed conditions. The five samples show a proeutectoid ferrite and pearlite microstructure, similar to the standard 22MnB5 grade shown in Figure 5(f). ${ }^{[19,20]}$ Pearlite has a lamellar structure of alternating plates of eutectoid ferrite and cementite. 


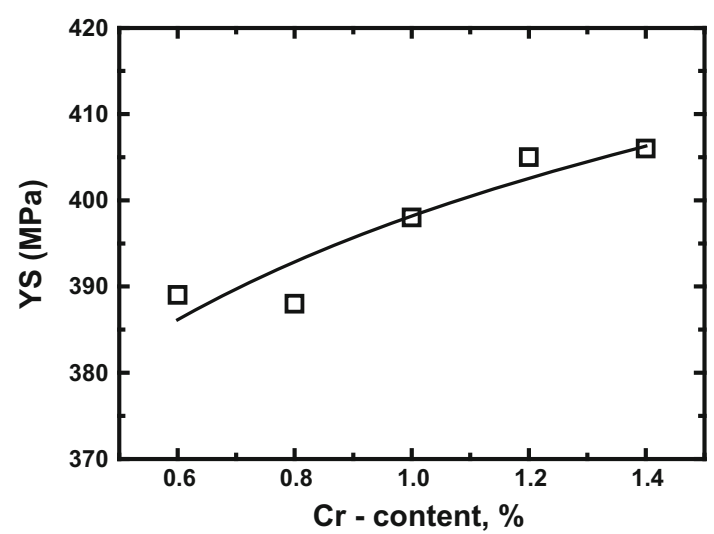

(a)

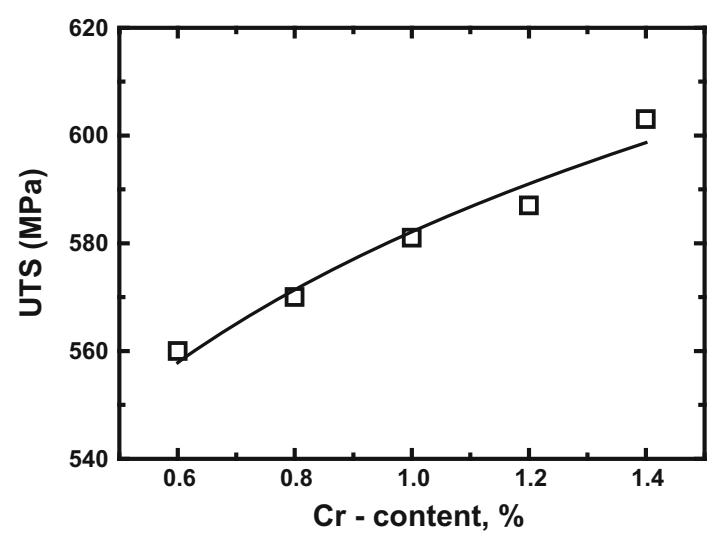

(b)

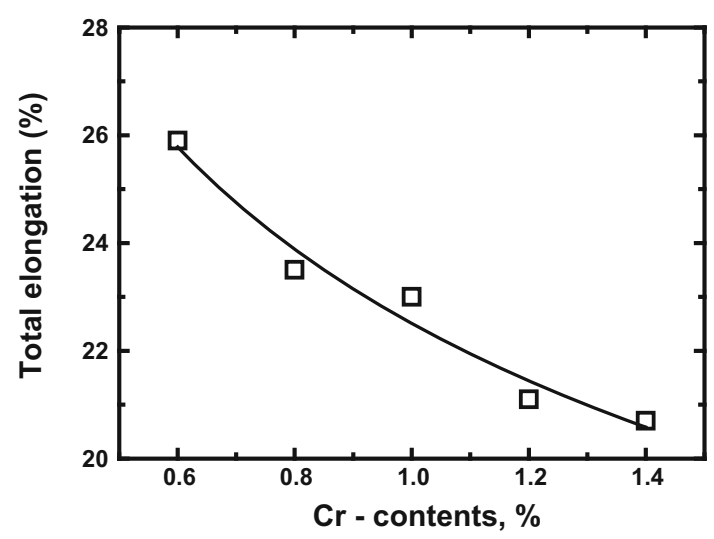

(c)

Fig. 6 - Tensile properties of as-received $22 \mathrm{MnCrN} 5-\mathrm{X}$ for $\mathrm{Cr}$ contents in the range of 0.6 to $1.4 \mathrm{wt}$ pct: $(a) \mathrm{YS},(b) \mathrm{UTS}$, and $(c)$ total elongation.

\section{B. Mechanical Properties of TSDR-Processed 22MnCrN5-X}

TSDR-processed 22MnCrN5-X has ferritic-pearlitic microstructure. Figure 6 shows the Cr-content dependence of the YS, UTS, and the total elongation for TSDR-processed 22MnrCrN5-X. The mechanical properties of hot-rolled $22 \mathrm{MnB} 5$ are typically as follows:
$\mathrm{YS} \approx 430, \quad \mathrm{UTS} \approx 600 \mathrm{MPa}$, and total elongation $\approx 25$ pct. Table II compares the difference of the tensile properties of $22 \mathrm{MnB} 5$ and $22 \mathrm{MnCrN} 5-\mathrm{X}$ prior to press hardening. The YS and the UTS of the 22MnCrN5-X PHS increased with increasing $\mathrm{Cr}$ content. The ductility decreased slightly with increasing $\mathrm{Cr}$ content. The tensile properties of $22 \mathrm{MnCrN5}-4$ prior to HPF simulation were comparable to those of the 22MnB5 PHS.

\section{CCT Diagram of 22MnCrN5-X}

Since ultra-high strength levels are required for passenger safety, a fully martensitic PHS microstructure must be achieved after HPF process. Boron is therefore the key hardenability addition in $22 \mathrm{MnB} 5$. The critical cooling rate for the martensitic transformation of the $22 \mathrm{MnB} 5$ PHS is approximately $-30{ }^{\circ} \mathrm{C} / \mathrm{s} .{ }^{[13]}$ The austenite decomposition kinetics for ferrite and bainite formation in the $22 \mathrm{MnCrN} 5-\mathrm{X}$ steel PHS was examined by means of continuous cooling tests from the austenitization temperature at constant cooling rates. The new TSDR-compatible steel does not contain B. Instead of $\mathrm{B}, \mathrm{Cr}$, which is a strong hardenability agent, is used. $\mathrm{Cr}$ is very efficient in retarding ferrite formation and suppressing the bainite transformation. $\mathrm{Cr}$ additions move the bainite transformation to lower temperatures in the continuous cooling transformation (CCT) diagrams. The $B_{\mathrm{s}}$ temperature is lowered by $\mathrm{Cr}$ additions. Kirkaldy and Venugopalan ${ }^{[21]}$ have proposed the following empirical composition-dependent equation for the $B_{\mathrm{s}}$ temperature:

$$
\begin{aligned}
B_{\mathrm{s}}\left({ }^{\circ} \mathrm{C}\right)= & 656-57.7 \mathrm{pct} \mathrm{C}-75 \mathrm{pct} \mathrm{Si}-35 \mathrm{pct} \mathrm{Mn}-15.3 \mathrm{pct} \mathrm{Ni} \\
& -34 \mathrm{pct} \mathrm{Cr}-41.2 \mathrm{pct} \mathrm{M} .
\end{aligned}
$$

Here, the concentrations are in mass pct. The ferrite and pearlite transformation range is also moved to lower temperatures by $\mathrm{Cr}$ additions. ${ }^{[22]}$ Figure 7 shows the CCT diagram obtained by dilatometry for the five $22 \mathrm{MnCrN5}$-X PHS. The transformation kinetics for ferrite and bainite are clearly retarded with increasing $\mathrm{Cr}$ content. It is due to the fact that $\mathrm{Cr}$ has a solute drag effect on the transformation interface, i.e., there is $\mathrm{Cr}$ enrichment associated at the $\gamma / \alpha$ phase boundary during the austenite decomposition. ${ }^{[22]}$ None of the $22 \mathrm{MnCrN5} \mathrm{X}$ steels transformed to ferrite for a cooling rate of $-70^{\circ} \mathrm{C} / \mathrm{s}$. The 0.6 wt pet $\mathrm{Cr}$ PHS had a small volume fraction of bainite in the microstructure after cooling with a $-70{ }^{\circ} \mathrm{C} / \mathrm{s}$ cooling rate. The same steel also contained some ferrite after transformation after cooling with $-50{ }^{\circ} \mathrm{C} / \mathrm{s}$ cooling rate. The samples containing $0.6 \mathrm{wt}$ pet $\mathrm{Cr}$ or higher did not contain bainite in their microstructures after cooling from austenite with a cooling rate of $-70{ }^{\circ} \mathrm{C} / \mathrm{s}$. The PHS with $0.8 \mathrm{wt}$ pct $\mathrm{Cr}$ had a small amount of ferrite after cooling with a $-70{ }^{\circ} \mathrm{C} / \mathrm{s}$ cooling rate. It contained some bainite after cooling with a $-50{ }^{\circ} \mathrm{C} / \mathrm{s}$ cooling rate. The PHS with 1.0 , 1.2 , and $1.4 \mathrm{wt}$ pet of $\mathrm{Cr}$ did not transform to ferrite even for a cooling rate of $-50{ }^{\circ} \mathrm{C} / \mathrm{s}$. The martensite start 
Table II. Tensile Properties and Hardness of 22MnCrN5-X after (a) Dilatometry with $50{ }^{\circ} \mathrm{C} / \mathrm{s}$ of Cooling Rate, (b) Dilatometry with $70^{\circ} \mathrm{C} / \mathrm{s}$ of Cooling Rate, (c) HPF Simulation with $50^{\circ} \mathrm{C} / \mathrm{s}$ of Cooling Rate, and (d) HPF Simulation with Die-Quenching

\begin{tabular}{lcccccrr}
\hline Steels & $\begin{array}{c}\text { Hardness } \\
(\mathrm{Hv},(\mathrm{a}))\end{array}$ & $\begin{array}{c}\text { Hardness } \\
(\mathrm{Hv},(\mathrm{b}))\end{array}$ & $\begin{array}{c}\text { Hardness } \\
(\mathrm{Hv},(\mathrm{c}))\end{array}$ & $\begin{array}{c}\text { Hardness } \\
(\mathrm{Hv},(\mathrm{d}))\end{array}$ & $\begin{array}{c}\text { YS } \\
(\mathrm{MPa},(\mathrm{c}))\end{array}$ & $\begin{array}{c}\text { YS } \\
(\mathrm{MPa},(\mathrm{d}))\end{array}$ & $\begin{array}{c}\text { UTS } \\
(\mathrm{MPa},(\mathrm{c}))\end{array}$ \\
\hline $0.6 \mathrm{Cr}$ & 349 & 422 & 342 & 462 & 778 & 988 & 1337 \\
$0.8 \mathrm{Cr}$ & 421 & 467 & 414 & 487 & 806 & 1007 & 1358 \\
$1.0 \mathrm{Cr}$ & 449 & 494 & 488 & 490 & 973 & 1005 & 1497 \\
$1.2 \mathrm{Cr}$ & 498 & 498 & 503 & 489 & 1074 & 998 & 1526 \\
$1.4 \mathrm{Cr}$ & 501 & 501 & 504 & 491 & 1090 & 1025 & 1474 \\
\hline
\end{tabular}

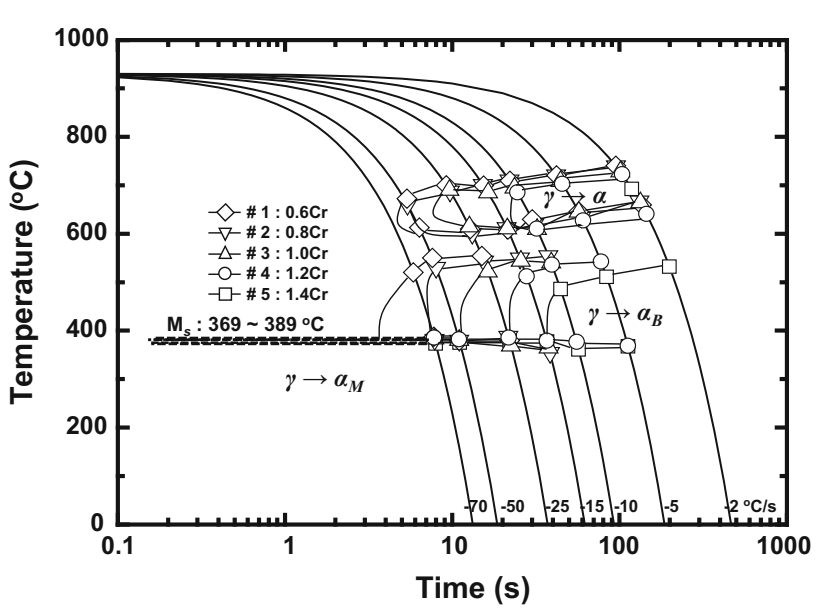

Fig. 7-Experiment CCT diagram for 22MnCrN5-X with different amounts of $\mathrm{Cr}$.

temperature $\left(M_{\mathrm{s}}\right)$ range of the $22 \mathrm{MnCrN} 5-\mathrm{X}$ alloys was $642 \mathrm{~K}$ to $662 \mathrm{~K}\left(369^{\circ} \mathrm{C}\right.$ to $\left.389^{\circ} \mathrm{C}\right)$.

D. Microstructure and Tensile Properties of 22MnCrN5$X$ after Cooling at a Rate of $-50{ }^{\circ} \mathrm{C} / \mathrm{s}$

The two different HPF simulations shown in Figure 4 were carried out to evaluate the $22 \mathrm{MnCrN} 5-\mathrm{X}$ PHS. The five $22 \mathrm{MnCrN5}$-X steels were cooled to room temperature using the thermal cycle as shown in Figure 4(a). The samples were heated to $1203 \mathrm{~K}\left(930^{\circ} \mathrm{C}\right)$ and held at this soaking temperature for 5 minutes. In the first simulation, a cooling rate of $-50^{\circ} \mathrm{C} / \mathrm{s}$ was used. Figure 8 shows the microstructures observed for the $22 \mathrm{MnrCrN5}-\mathrm{X}$ PHS after this HPF simulation. The microstructure of $22 \mathrm{MnCrN5}$-X PHS is clearly $\mathrm{Cr}$ content-dependent. The microstructure of the PHS with 0.6 and 0.8 wt pet $\mathrm{Cr}$ consisted mainly of bainite and martensite with a small volume fraction of ferrite. The PHS with $1.0 \mathrm{wt}$ pet $\mathrm{Cr}$ had an almost fully martensitic microstructure and a small volume fraction of bainite. The PHS with 1.2 and $1.4 \mathrm{wt}$ pet $\mathrm{Cr}$ had a fully martensitic microstructure. The microstructure results of the $22 \mathrm{MnCrN5}$-X PHS after the first HPF simulation correspond to the microstructures predicted by the CCT diagram.

Figure 9 shows the Cr-content dependence of the YS, UTS, and the total elongation for 22MnrCrN5-X after the
HPF simulation of Figure 4(a). Three tensile tests were carried out for each specimen, and the YS, UTS, and total elongation results shown in this figure are average values. The YS and the UTS increase with increasing Cr content. The YS and UTS of the 22MnCrN5-X PHS were clearly affected by the Cr-content-dependent microstructure. The samples with 0.6 and 0.8 wt pet $\mathrm{Cr}$ had a lower strength due to the presence of the softer ferrite and bainite phases. The PHS with 1.0 wt pct $\mathrm{Cr}$, which contained bainite and martensite, has a YS of about $970 \mathrm{MPa}$ and a UTS of about $1500 \mathrm{MPa}$. The PHS with 1.2 and $1.4 \mathrm{wt}$ pet Cr, which had fully martensitic microstructures, had a YS $>1000 \mathrm{MPa}$ and a UTS of about $1500 \mathrm{MPa}$. The UTS of the PHS with 1.0, 1.2, and $1.4 \mathrm{wt}$ pet $\mathrm{Cr}$ was comparable to the UTS for the conventional $22 \mathrm{MnB} 5$ PHS grade. The 22MnCrN5-X PHS generally achieved a better ductility value than the 22MnB5 PHS grade.

\section{E. Microstructure and Tensile Properties of Die-Quenched 22MnCrN5-X PHS}

Die-quenching is a commonly used for the combined forming and quenching of ultra-high strength steel in industrial conditions. A flat die was used to simulate the HPF of $22 \mathrm{MnCrN5}$-X in the present work. There was no simultaneous deformation during the die-quenching. Figure 10 shows the microstructure after the diequenching of the 22MnCrN5-X PHS as a function of the $\mathrm{Cr}$ content. The 0.6 wt pet Cr PHS had an almost a fully martensitic microstructure, containing a small amount of bainite. The PHS with $0.8,1.0,1.2$, and 1.4 wt pet $\mathrm{Cr}$ had a fully martensitic microstructure. The cooling rate during die-quenching can therefore be assumed to be more than $-50{ }^{\circ} \mathrm{C} / \mathrm{s}$. Based on the CCT diagram (Figure 7), it is assumed that the cooling rate during the die-quenching simulation was approximately $-70{ }^{\circ} \mathrm{C} / \mathrm{s}$.

Figure 11 shows the Cr-content dependence of the YS, UTS, and the total elongation of the $22 \mathrm{MnrCrN5}$-X PHS after the flat die-quenching test. The sample with 0.6 wt pet $\mathrm{Cr}$ had a YS of $\sim 1000 \mathrm{MPa}$ and a UTS of $\sim 1440 \mathrm{MPa}$. The samples with $0.8,1.0,1.2$, and $1.4 \mathrm{wt}$ pet $\mathrm{Cr}$ had a YS $>1000 \mathrm{MPa}$ and a UTS of $\sim 1470 \mathrm{MPa}$. The PHS with 0.6 wt pet $\mathrm{Cr}$ had lower values for the YS and UTS as compared with the other PHS due to the presence of a small volume fraction of bainite. 

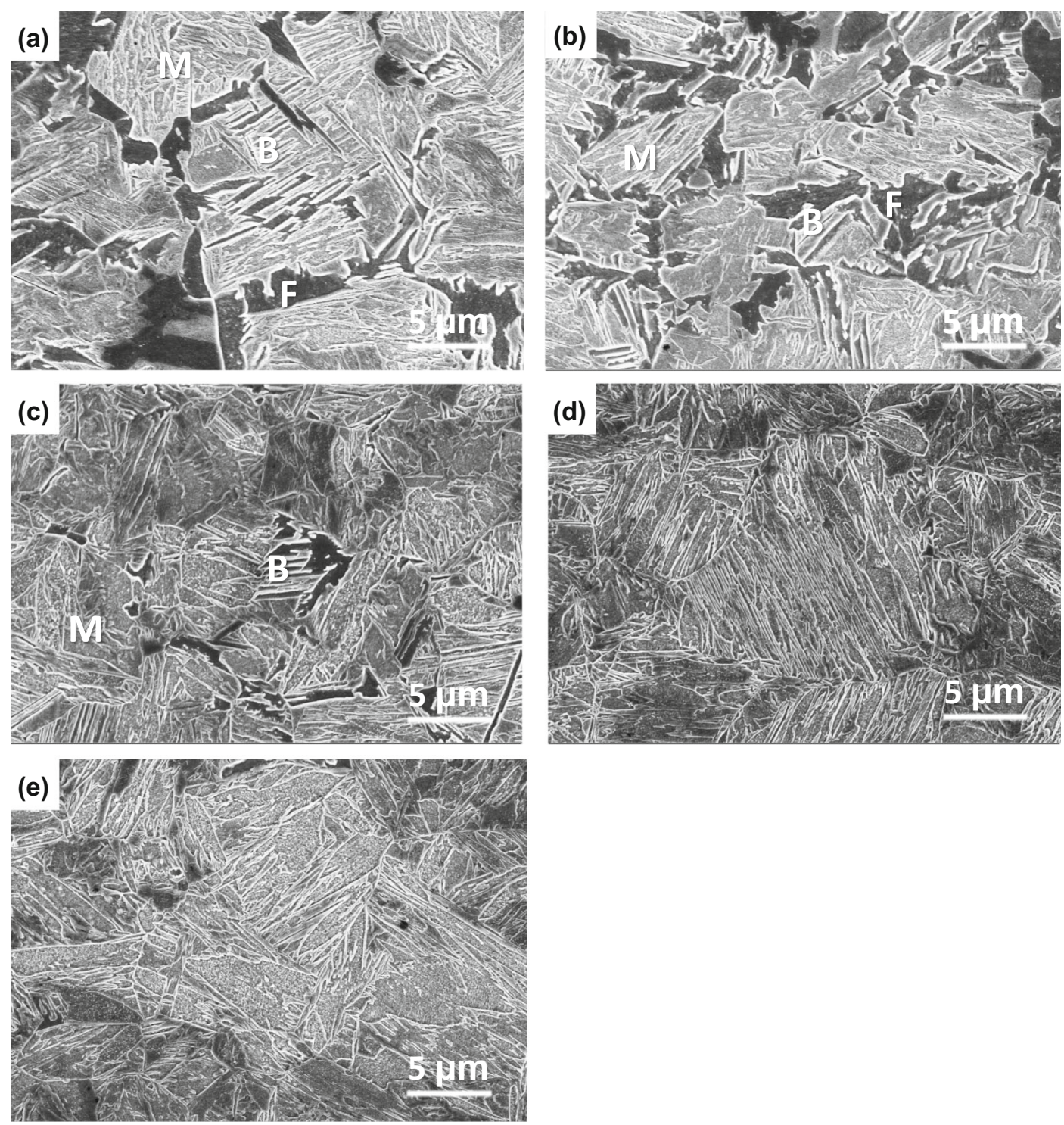

Fig. 8- Microstructure of hot-rolled $22 \mathrm{MnCrN} 5-\mathrm{X}$ with different amounts of $\mathrm{Cr}$ after the first $\mathrm{HPF}$ simulation using a cooling rate of $50{ }^{\circ} \mathrm{C} / \mathrm{s}$ : (a) 0.6, (b) 0.8, (c) 1.0, (d) 1.2, and (e) $1.4 \mathrm{wt}$ pct Cr. The microstructures in (d) (b) and (e) are fully martensitic.

Table II compares the tensile properties and the hardness after the heat treatments applied during dilatometry, the HPF simulation with a cooling rate of $-50{ }^{\circ} \mathrm{C} / \mathrm{s}$, and the HPF simulation using diequenching. The hardness results of the $22 \mathrm{MnCrN5}-\mathrm{X}$ PHS after the HPF simulation using a $-50{ }^{\circ} \mathrm{C} / \mathrm{s}$ cooling rate are similar to those obtained for the PHS heat-treated by dilatometry using a $-50{ }^{\circ} \mathrm{C} / \mathrm{s}$ cooling rate. The hardness results of the $22 \mathrm{MnCrN5}$-X PHS after die-quenching corresponded to those for samples heat-treated by dilatometry using a $-70{ }^{\circ} \mathrm{C} / \mathrm{s}$ cooling rate. A relatively small amount of $\mathrm{Cr}$, i.e., $0.8 \mathrm{wt}$ pct $\mathrm{Cr}$, is therefore sufficient to achieve a UTS of $\sim 1470 \mathrm{MPa}$ after die-quenching. The YS and the UTS of the PHS with 1.2 and 1.4 wt pet of $\mathrm{Cr}$, which are fully martensitic after the two HPF simulations, were slightly lower after die-quenching as compared with those after a HPF simulation with a $-50{ }^{\circ} \mathrm{C} / \mathrm{s}$ cooling rate.

\section{DISCUSSION}

Cr-containing cementite precipitates are formed during the pearlite transformation which takes place during coiling of the hot-rolled steel. Since carbide precipitates pin the newly nucleated ferrite grain boundaries, a smaller ferrite grain size can be attained when a higher volume fraction of $\mathrm{Cr}$-carbides precipitates in steel. The results in Table II show that a finer ferrite grain size was obtained for higher contents of $\mathrm{Cr}$. The average ferrite grain size of the sample with 


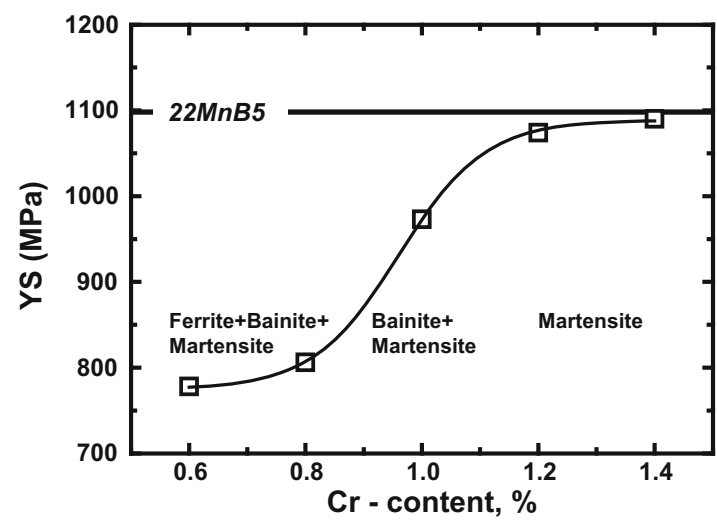

(a)

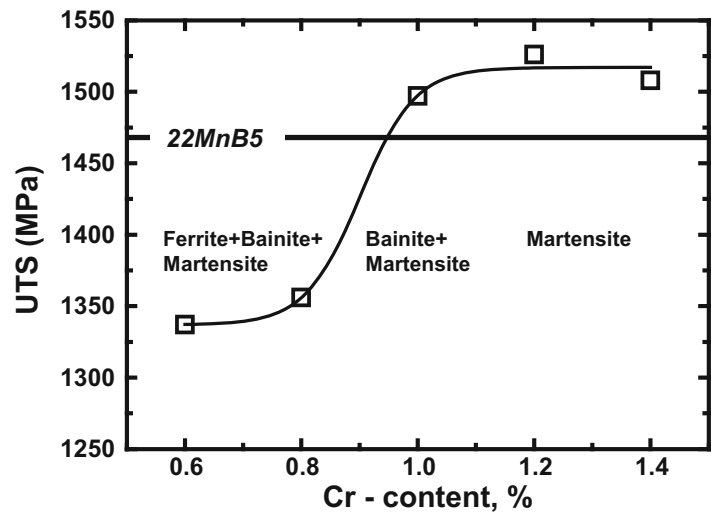

(b)

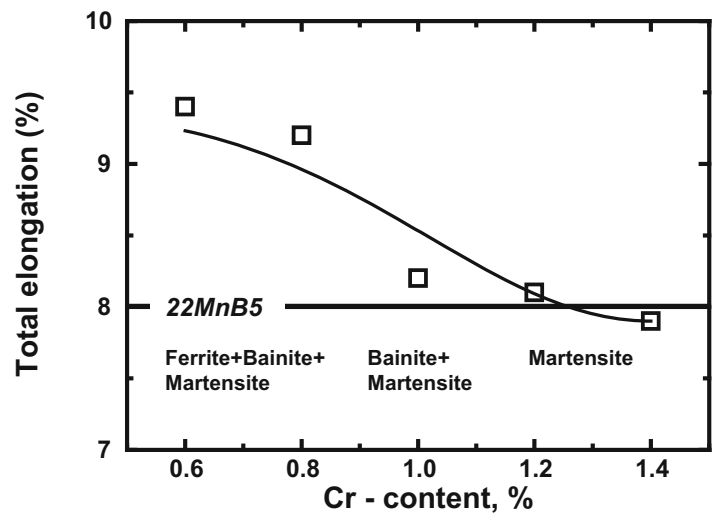

(c)

Fig. 9-Tensile properties of hot-rolled $22 \mathrm{MnCrN5}-4$ with different amounts of $\mathrm{Cr}$ after the first HPF simulation with $50{ }^{\circ} \mathrm{C} / \mathrm{s}$ of cooling rate: (a) YS, (b) UTS, and (c) total elongation.

$1.4 \mathrm{wt}$ pet of $\mathrm{Cr}$ was the smallest because the larger volume fraction of chromium carbides precipitate resulted in an efficient grain boundary pinning effect. ${ }^{[23]}$ The Cr-content dependence of the average ferrite grain size and its effect on the tensile properties of hot-rolled $22 \mathrm{MnCrN5}-\mathrm{X}$ are illustrated in Figure 6. The YS and UTS were increased with increasing $\mathrm{Cr}$ content. This increased strength is due to a combination of an increased precipitation hardening and a grain size reduction brought about by the $\mathrm{Cr}$ additions. The presence of second phase particles such as $\mathrm{Cr}$ carbide precipitates inhibits the dislocation motion. Since these particles increase the stress required for plastic deformation, a higher strength was obtained. The finer grain size of sample with a higher $\mathrm{Cr}$ content can be explained by the fact that $\mathrm{Cr}$ carbide precipitates pin the grain boundaries and inhibit grain growth. The finer grain size also results in an increased YS and flow stress as expressed in the Hall-Petch relationship. Figure 12 shows engineering strength-strain curves for $22 \mathrm{MnB} 5$ and $22 \mathrm{MnCrN5}-4$ before and after the die-quenching process. A yield point phenomena was observed for both the 22MnB5 and 22MnCrN5-4 PHS. Both PHS had a ferrite and pearlite microstructure before die-quenching. The presence of a discontinuous yielding is related to the interaction of interstitial $\mathrm{C}$ or $\mathrm{N}$ and dislocations in the ferrite phase. A continuous yielding behavior was observed for both $22 \mathrm{MnB} 5$ and 22MnCrN5-4 PHS which had a fully martensitic microstructure after die-quenching. When martensite is formed from austenite, the volume change associated with the transformation leads to local compressive stresses, and a high density of mobile dislocations is generated. The presence of these dislocations brings about the continuous yielding behavior. ${ }^{[22]}$ Table III shows the tensile properties of $22 \mathrm{MnCrN5}-4$ and $22 \mathrm{MnB} 5$ before and after die-quenching. Both the YS and the UTS of the 22MnCrn5-4 PHS after diequenching were slightly lower than those of the $22 \mathrm{MnB} 5 \mathrm{PHS}$. The total elongation of the 22MnCrN5-4 PHS after die-quenching was slightly higher than for the 22MnB5 PHS. Both strength and total elongation of $22 \mathrm{MnCrN5}-4$ were slightly lower before die-quenching compared with the $22 \mathrm{MnB} 5$ PHS. The higher YS of the 22MnB5 PHS before die-quenching is very likely due to its finer ferrite grain size as shown in Table II.

Figure 13 shows dilatometry curves for $22 \mathrm{MnCrN} 5-4$ during cooling with $\mathrm{a}-50{ }^{\circ} \mathrm{C} / \mathrm{s}$ cooling rate. The microstructures of the 22MnCrN5-X PHS after cooling are shown in Figure 9. The dilatometry results show that the samples with 0.6 and $0.8 \mathrm{wt}$ pct $\mathrm{Cr}$ experienced the ferrite, bainite, and martensite transformations during cooling. The sample with $1.0 \mathrm{wt}$ pet $\mathrm{Cr}$ experienced the bainite and martensite transformations. The samples with 1.2 and 1.4 wt pet $\mathrm{Cr}$ transformed fully to martensite upon cooling with a cooling rate of $-50{ }^{\circ} \mathrm{C} / \mathrm{s}$. Figure 14 shows fractional changes of austenite decomposition phases during cooling as calculated from the dilatometry curves as shown in Figure 13. Since the samples with 1.2 and 1.4 wt pet $\mathrm{Cr}$ transformed fully to martensite during cooling with a cooling rate of $-50{ }^{\circ} \mathrm{C} / \mathrm{s}$, the volume of martensite for other samples with $0.6,0.8$, and 1.0 wt pet $\mathrm{Cr}$ can be also estimated using Figure 14. Table IV lists the ferrite, bainite, and martensite transformation start temperatures $\left(F_{\mathrm{s}}, B_{\mathrm{s}}\right.$, and $\left.M_{\mathrm{s}}\right)$ and volume fraction of martensite for $22 \mathrm{MnCrN} 5-\mathrm{X}$ PHS. The sample with $0.6 \mathrm{wt}$ pct $\mathrm{Cr}$ contained $\sim 35$ vol pct 

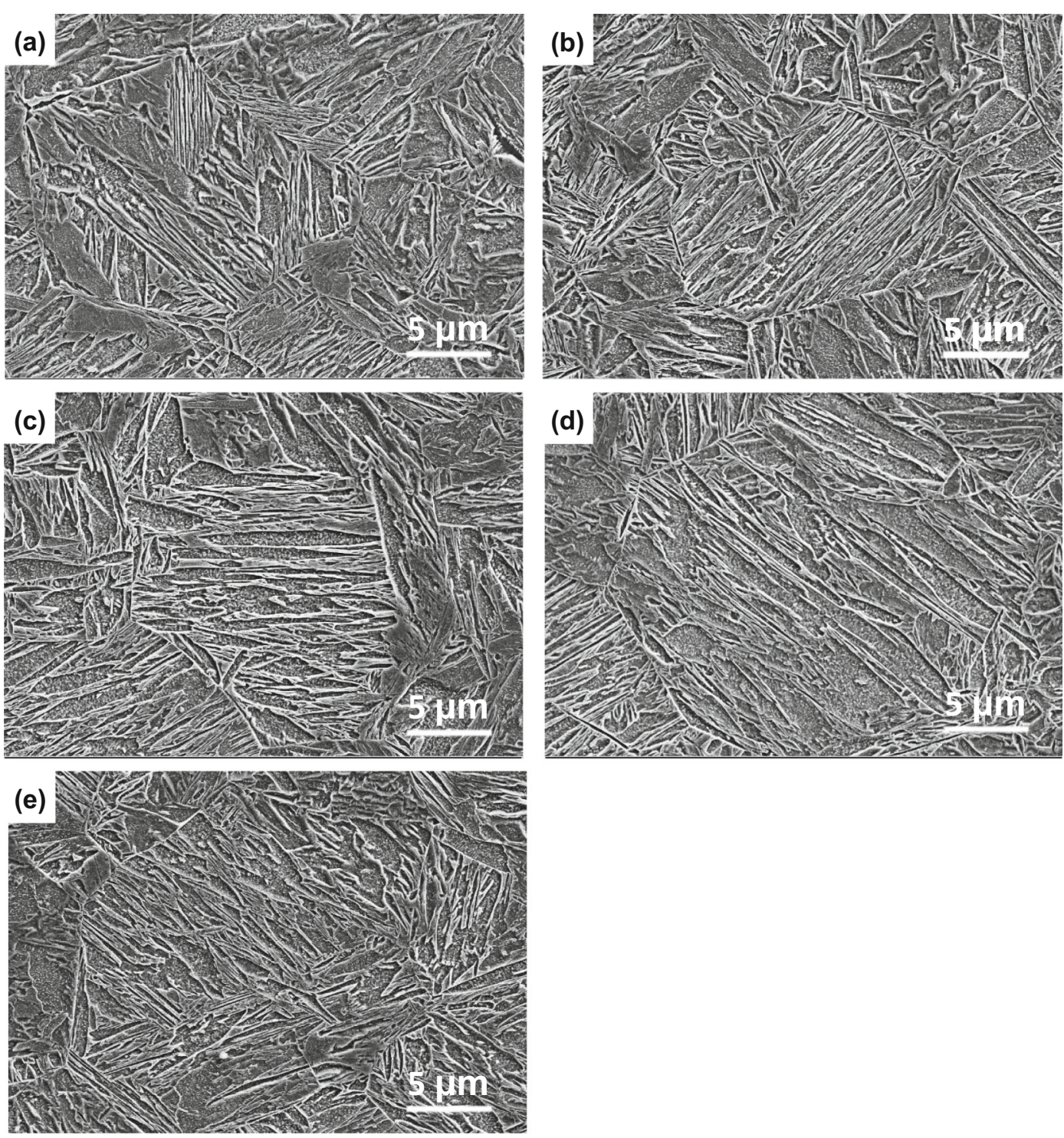

Fig. 10-Microstructure of the hot-rolled 22MnCrN5-X with different amounts of $\mathrm{Cr}$ after the HPF die-quenching: $(a) 0.6,(b) 0.8,(c) 1.0,(d)$ 1.2 , and (e) $1.4 \mathrm{wt}$ pet $\mathrm{Cr}$. The microstructure is partially martensitic in (a). The microstructures of (b) to (e) are fully martensitic.

martensite, which is the smallest amount of the five samples because a relatively larger of the volume fraction of austenite transformed to ferrite and bainite during cooling. The sample with $0.8 \mathrm{wt}$ pet $\mathrm{Cr}$ had $\sim 40$ pct volume of martensite, and the sample with 1.0 wt pct Cr sample had 75 pct volume of martensite. The samples with 1.2 and 1.4 wt pet $\mathrm{Cr}$ were fully martensitic. The $F_{\mathrm{s}}$ and $B_{\mathrm{s}}$ temperatures were slightly decreased with increasing $\mathrm{Cr}$ content. The $M_{\mathrm{s}}$ temperatures of the steels containing $1.2 \mathrm{wt}$ pct $\mathrm{Cr}$ and 1.4 wt pet $\mathrm{Cr}$ which had with a fully martensitic microstructure $(1.2$ and $1.4 \mathrm{Cr})$ were higher than for samples which experienced a ferrite, bainite, and martensite transformations. This is due to the fact that the stability of the untransformed austenite during cooling is increased due to an increase of the carbon content of the untransformed austenite during bainite transformation. This increased carbon content of the untransformed austenite results in its increased stability and hence a lowering of its $M_{\mathrm{s}}$ temperature. ${ }^{[23-25]}$

\section{CONCLUSIONS}

An EAF-based TSDR-compatible PHS steel concept has been developed which allows for the production of a low cost, thin gauge hot-rolled alternative to the standard cold-rolled, and recrystallization-annealed $22 \mathrm{MnB} 5$ PHS grade. This Ti and B free 22MnCrN5-X steel exploits the high $\mathrm{N}$ content of steel produced in an EAF for solid solution strengthening. Cr, rather than B, is used as the hardenability agent. $\mathrm{C}$ and $\mathrm{Mn}$ contents 


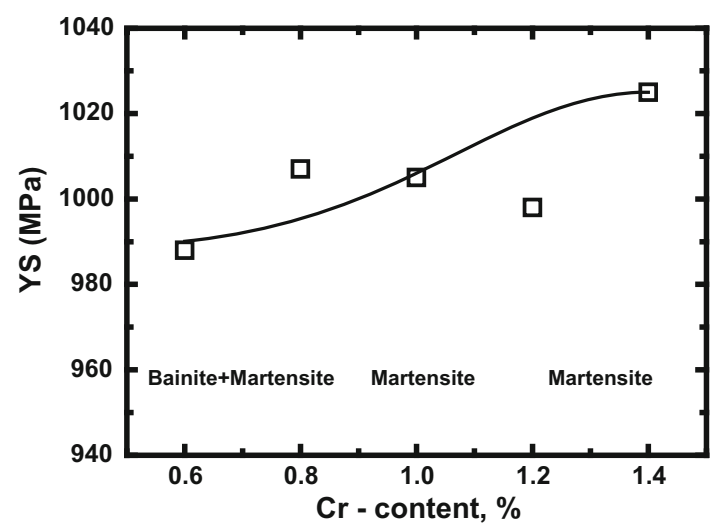

(a)

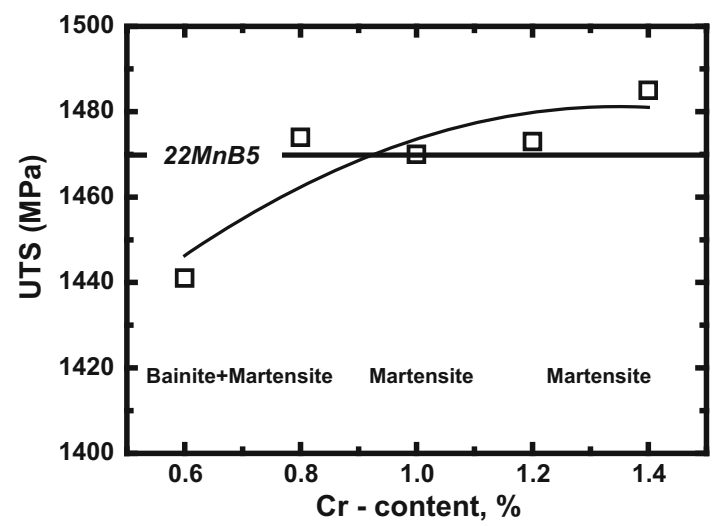

(b)

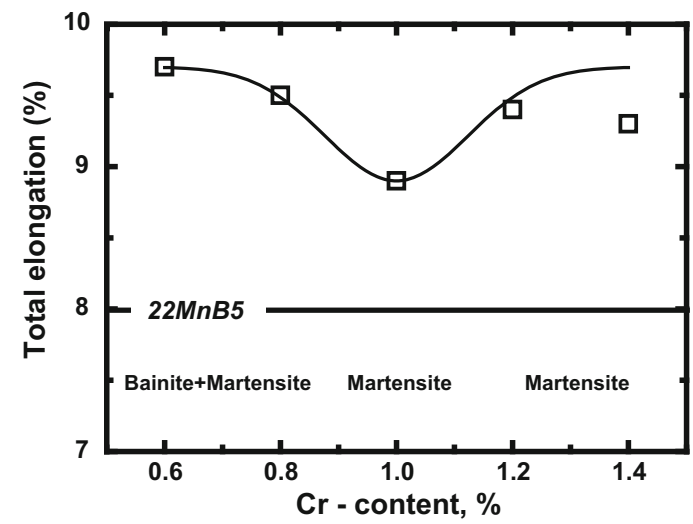

(c)

Fig. $11-$ Tensile properties of hot-rolled $22 \mathrm{MnCrN5}-4$ with different amounts of $\mathrm{Cr}$ after HPF simulation by means of die-quenching: (a) YS, (b) UTS, and (c) total elongation.

are maintained at the same levels as for the conventional 22MnB5 PHS. In addition, this newly proposed PHS concept is particularly suitable for TSDR processing because the absence of $\mathrm{Ti}$ addition makes it possible to avoid transverse cracking in the high casting speed conditions used during TSDR processing. The optimal addition of $\mathrm{Cr}$ in the range of 0.8 to $1.0 \mathrm{wt}$ pet was determined on the basis of CCT diagrams. Microstructural changes and tensile properties of the $22 \mathrm{MnCrN} 5-\mathrm{X}$ alloyed were investigated in function of the $\mathrm{Cr}$ content

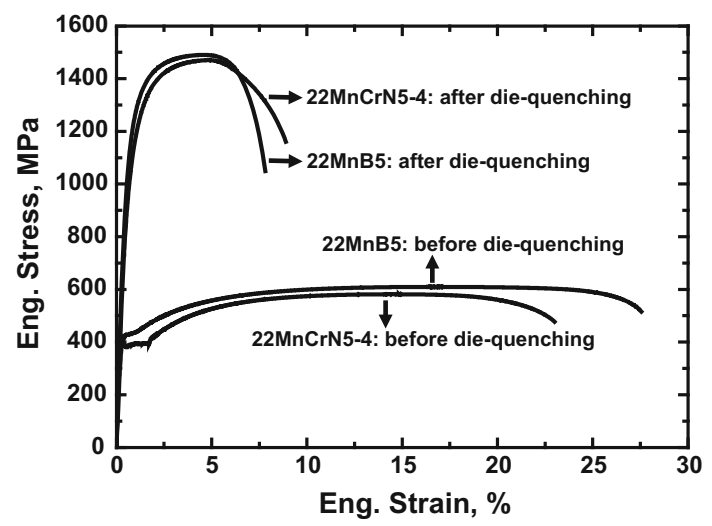

Fig. 12 - Tensile properties of $22 \mathrm{MnB} 5$ and $22 \mathrm{MnCrN} 5-4$ before and after die-quenching.

Table III. Tensile Properties of 22MnB5 and 22MnCrN5-4 PHS (a) before and (b) after Die-Quenching

\begin{tabular}{lcccc}
\hline & $\begin{array}{c}\text { YS } \\
\text { Steels }\end{array}$ & $\begin{array}{c}\text { UTS } \\
\text { (MPa) }\end{array}$ & $\begin{array}{c}\text { Uniform } \\
\text { Elongation } \\
\text { (pct) }\end{array}$ & $\begin{array}{c}\text { Total } \\
\text { Elongation } \\
\text { (pct) }\end{array}$ \\
\hline 22MnB5 (a) & 427 & 609 & 16.9 & 27.5 \\
22MnCrN5-4 (a) & 388 & 581 & 14.5 & 23.3 \\
22MnB5 (b) & 1095 & 1490 & 4.6 & 7.8 \\
22MnCrN5-4 (b) & 1005 & 1470 & 4.8 & 8.9 \\
\hline
\end{tabular}

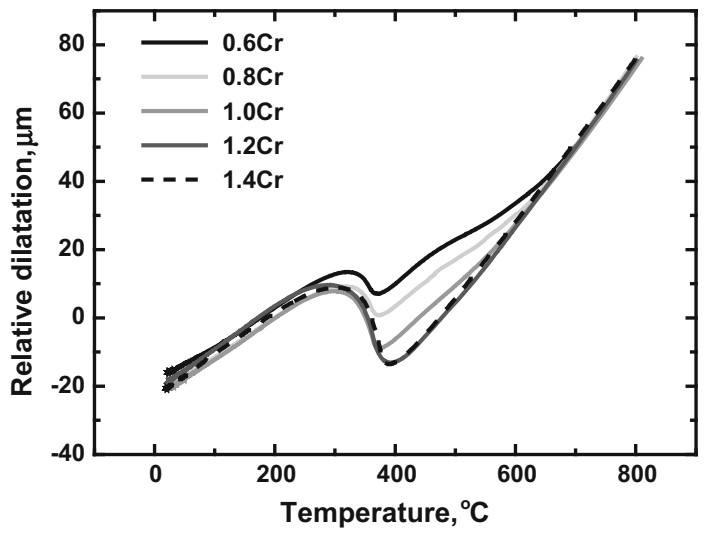

Fig. 13-Dilatometric curves for $22 \mathrm{MnCrN} 5-\mathrm{X}$ for a cooling rate of $-50{ }^{\circ} \mathrm{C}$.

in the range of 0.6 to $1.4 \mathrm{wt}$ pct $\mathrm{Cr}$. The major findings of this study are as follows:

1. The use of the TSDR processing route means that the 22MnCrN5-X PHS grade contains no Ti and B additions. The high $\mathrm{N}$ content, resulting from EAF steel making, can therefore be used as an additional contribution to solid solution strengthen. The addition of $\mathrm{Cr}$ to the $22 \mathrm{MnCrN} 5-\mathrm{X}$ PHS provides the necessary hardenability. 


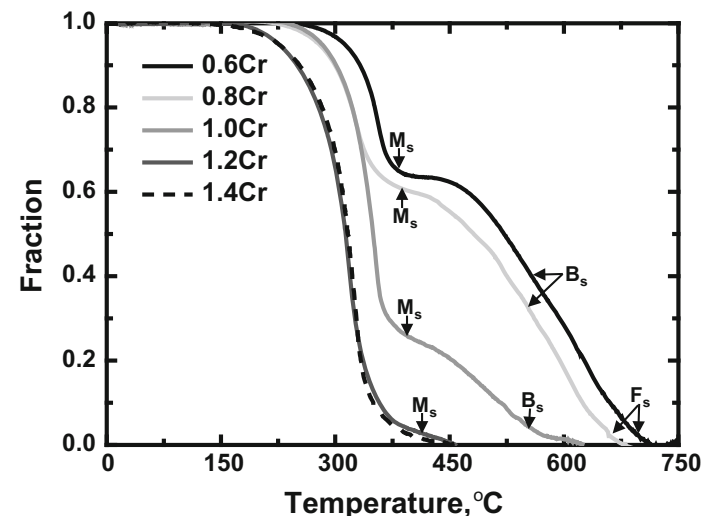

Fig. 14 -Austenite decomposition during cooling with a $-50{ }^{\circ} \mathrm{C} / \mathrm{s}$ of cooling rate.

Table IV. Ferrite, Bainite, and Martensite Transformation Start Temperatures and Volume Percentage of Martensite for 22MnCrN5-4 PHS Obtained after a Cooling Rate of $-50{ }^{\circ} \mathrm{C} / \mathrm{s}$

\begin{tabular}{lcccc}
\hline & $\begin{array}{c}F_{\mathrm{s}} \\
\text { Steels }\end{array}$ & $\begin{array}{c}B_{\mathrm{s}} \\
\text { Temperature }\end{array}$ & $\begin{array}{c}M_{\mathrm{s}} \\
\text { Temperature }\end{array}$ & $\begin{array}{c}\text { Volume } \\
\text { Temperature }\end{array}$ \\
\hline $0.6 \mathrm{Cr}$ & 702 & 568 & 369 & $\sim 35$ \\
$0.8 \mathrm{Cr}$ & 698 & 562 & 371 & $\sim 40$ \\
$1.0 \mathrm{Cr}$ & - & 557 & 375 & $\sim 75$ \\
$1.2 \mathrm{Cr}$ & - & - & 389 & 100 \\
$1.4 \mathrm{Cr}$ & - & - & 386 & 100 \\
\hline
\end{tabular}

2. Dilatometry was used to obtain CCT diagrams for the 22MnCrN5-X PHS grade. The formation kinetics of ferrite and bainite were found to be gradually retarded with increasing $\mathrm{Cr}$ additions.

3. A UTS of about $1500 \mathrm{MPa}$ was obtained for 22MnB5-4 after cooling with a cooling rate of $-50{ }^{\circ} \mathrm{C} / \mathrm{s}$.

\section{REFERENCES}

1. J.M. Rodriguez-Ibabe: Thin Slab Direct Rolling of Microalloyed Steels, 1st ed., Trans Tech Publications, Zurich, 2007.

2. M. Hara, H. Kikuchi, M. Hanao, M. Kawamoto, T. Murakami, and T. Watanabe: Rev. Metall., 2002, vol. 99, p. 367.

3. C. Yos: Commercialization of New Manufacturing Processes for Materials, 1998, vol. 57, p. 48.

4. J.M. Rodriguez-Ibabe: Mater. Sci. Forum, 2005, vols. 500-501, p. 49.

5. M. Millet: Thinner Slab Casting, 33rd McMaster Symposium, 2005, vol. 1, p. 262

6. N. Zapuskalo: ISIJ Int., 2003, vol. 43, p. 1115.

7. G. Berglund, K. Kallstrom, and L. Melin: 11th International DeepDrawing Research Group Congress, (C/43/80), 1980, p. 635.

8. M. Jonsson: "Products in Hot Stamped Boron Steel", Great Designs in STEEL Seminar, 2006.

9. B. Macek: "Optimization Side Crash Performance Using a HotStamped B-Pillar", Great Designs in STEEL Seminar, 2006.

10. J. Lechler, M. Merklein, and M. Geiger: Steel Res. Int., 2009, vol. 79, pp. 98-104.

11. M. Naderi, L. Durrenberger, A. Molinari, and W. Bleck: Mater. Sci. Eng. A, 2008, vol. 478, pp. 130-39.

12. M.C. Somani, L.P. Karjalainen, M. Eriksson, and M. Oldenburg: ISIJ Int., 2001, vol. 41, pp. 361-67.

13. T. Asai: "Hot Stamping Drawability of Steel", IDDRG 2004, Sindelfingen, Germany, 2004.

14. D. Berglund, Hot Stamped Components with Tailored Properties, 1st International Conference on Hot Sheet Metal Forming of High-Performance Steel, Lulea, Sweden, 2009.

15. G. Berglund: The History of Hardening of Boron Steel in Northern Sweden, 2nd International Conference on Hot Sheet Metal Forming of High-Performance Steel, Lulea, Sweden, 2008.

16. J.M. Rodriguez-Ibabe: Mater. Sci. Forum, 2005, vol. 49, pp. 500501 .

17. F. Steela, P. Bobig, A. Carboni, and I. Faruk: Intern. Symp. Thin Slab Rolling, 2002, p. 49.

18. M. Merklein, J. Lechler, and M. Geiger: CIRP Ann., 2006, vol. 55, pp. $229-32$

19. R. Kolleck, S. Pfanner, and E.P. Warnke: Key Eng. Mater., 2007, vol. 344 , pp. $225-32$.

20. H. Karbasian and A.E. Tekkaya: J. Mater. Process. Technol., 2010, vol. 210, pp. 2103-18.

21. J.S. Kirkaldy and D. Venugopalan: Phase Transformation in Ferrous Alloys, TMS, Warrendale, PA, 1984, p. 125.

22. B.C. De Cooman and J.G. Speer: Fundamentals of Steel Product Physical Metallurgy, 3rd ed., AIST, Warrendale, PA, 2012.

23. C. Zener, quoted by C.S. Smith: Trans. AIME., 1948, vol. 175, pp. $15-51$.

24. P. Payson and H. Savage: Trans ASM., 1944, vol. 33, pp. 261-80.

25. K.W. Andrews: JISI, 1965, vol. 203, pp. 721-27. 